(2) institute of development studies

Working Paper

Volume 2021 Number 546

Who Can We Count On?

Authority, Empowerment

and Accountability in

Mozambique

Egídio Chaimite, Salvador Forquilha and Alex Shankland

February 2021 
The Institute of Development Studies (IDS) delivers world-class research, learning and teaching that transforms the knowledge, action and leadership needed for more equitable and sustainable development globally.

Action for Empowerment and Accountability (A4EA) is an international research programme which explores how social and political action can contribute to empowerment and accountability in fragile, conflict, and violent settings, with a particular focus on Egypt, Mozambique, Myanmar, Nigeria, and Pakistan.

Led by the Institute of Development Studies, A4EA is being implemented by a consortium which includes: the Accountability Research Center, the Collective for Social Science Research, the Institute of Development and Economic Alternatives, Itad, Oxfam GB, and the Partnership for African Social and Governance Research. It is funded with UK aid from the UK government (Foreign, Commonwealth \& Development Office - FCDO, formerly DFID). The views expressed in this publication do not necessarily reflect the official policies of our funder.

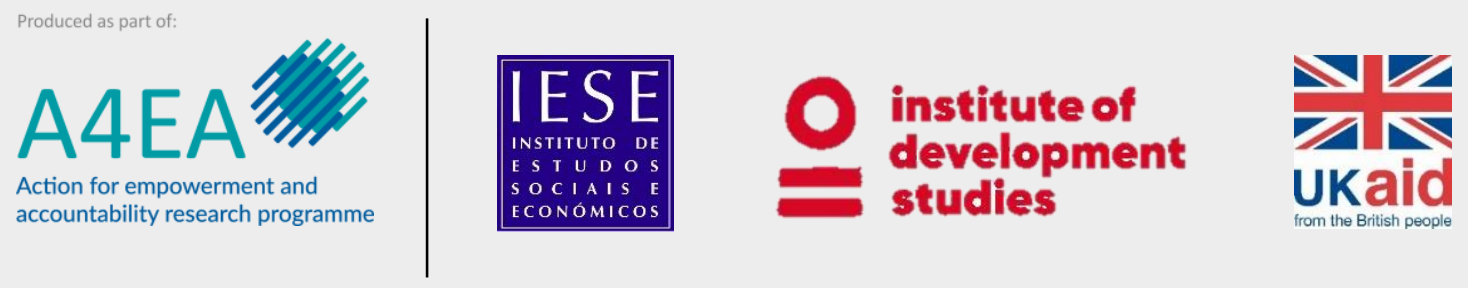

(C) Institute of Development Studies 2021

Working Paper Volume 2021 Number 546

Who Can We Count On? Authority, Empowerment and Accountability in Mozambique

Egídio Chaimite, Salvador Forquilha and Alex Shankland

February 2021

First published by the Institute of Development Studies in February 2021

ISSN: 2040-0209 ISBN: 978-1-78118-764-7

DOI: $10.19088 / I D S .2021 .019$

Suggested citation: Chaimite, E.; Forquilha, S. and Shankland, A. (2021) Who Can We Count On? Authority, Empowerment and Accountability in Mozambique, IDS Working Paper 546, Brighton: Institute of Development Studies, DOI: 10.19088/IDS.2021.019

A catalogue record for this publication is available from the British Library

This paper is funded with UK aid from the UK government (Foreign, Commonwealth \& Development Office FCDO, formerly DFID). The opinions are the authors and do not necessarily reflect the views or policies of IDS or the UK government.

This is an Open Access paper distributed under the terms of the Creative Commons Attribution 4.0 International licence (CC BY), which permits unrestricted use, distribution, and reproduction in any medium, provided the original authors and source are credited and any modifications or adaptations are indicated.

Available from:

Institute of Development Studies, Library Road

Brighton, BN1 9RE, United Kingdom

+44 (0)1273 915637

ids.ac.uk

IDS is a charitable company limited by guarantee and registered in England

Charity Registration Number 306371

Charitable Company Number 877338 
Working Paper

Volume 2021 Number 546

Who Can We Count On? Authority, Empowerment and Accountability in Mozambique

Egídio Chaimite, Salvador Forquilha and Alex Shankland February 2021 


\title{
Who Can We Count On? Authority, Empowerment and Accountability in Mozambique
}

\author{
Egídio Chaimite, Salvador Forquilha and Alex Shankland \\ February 2021
}

\section{Summary}

In this paper, we explore the use of a governance diaries methodology to investigate poor households' interactions with authority in fragile, conflict and violence-affected settings in Mozambique. The research questioned the meanings of empowerment and accountability from the point of view of poor and marginalised people, with the aim of understanding what both mean for them, and how that changes over time, based on their experiences with governance. The study also sought to record how poor and marginalised households view the multiple institutions that govern their lives; providing basic public goods and services, including health and security; and, in return, raise revenues to fund these services.

The findings show that, even if the perceptions and, with them, the concepts of empowerment and accountability that emerged do not differ significantly from those identified in the literature, in terms of action and mobilisation there are distinctions. In our research sites we found that people rarely mobilise, even faced with prevalent injustices and poor basic service provision. Many claim to be 'unable' to influence or force 'authorities' to respond to their concerns and demands.

\section{Keywords}

Governance; accountability; empowerment; conflict; research methodologies; fragility. 


\section{Authors}

Egídio Chaimite is a researcher with the Citizenship and Governance Research Group of the Institute for Social and Economic Studies (IESE) in Maputo, Mozambique, and a PhD candidate at the Institute of Development Studies, University of Sussex. He holds a master's degree in political sciences from Sciences Po Bordeaux, France. His research focuses on elections, governance, and social movements.

Salvador Forquilha is Director of IESE and a Senior Lecturer at the Department of Political Science and Public Administration, Eduardo Mondlane University in Maputo, Mozambique. He holds a PhD in Political Science from the University of Bordeaux, France. His research focuses on decentralisation, public services, conflict, and political violence.

Alex Shankland is a Research Fellow in the Power and Popular Politics Cluster at the Institute of Development Studies. He is a social scientist with over two decades' experience of working in Brazil, Peru, Angola, and Mozambique as a researcher, non-governmental organisation manager, and social development consultant. He has researched, taught, and published extensively on rights, participation and policy, particularly in the health sector, and his doctoral thesis was on representation and health policy in the Brazilian Amazon. His current research interests centre on theories and practices of democratic representation and citizen-state engagement, with particular reference to the political strategies of indigenous peoples and other marginalised minorities engaging with development and climate change policies. 


\section{Contents}

Acknowledgements

1. Introduction

2. Country context

3. The Diaries

3.1 Methods

3.1.1 Locations and households selection

3.1.2 Data collection and analysis

4. Accessing services

4.1 Health

4.2 Security and justice

4.3 Taxation

5. 'Who can we count on?' Trust, legitimacy, public authority, and state

5.1 Legitimacy and trust

5.2 Public authority

5.3 State

6. Empowerment and accountability

6.1 Empowerment

6.2 Accountability

7. Concluding thoughts: local authorities as intermediaries? 
Box

Box 5.1 The Mualadzi Natural Resources Management and Development Committee

\section{Figures}

Figure 3.1 Example of institutional map design health issues 15

Figure 3.2 Drafting institutional map on household income 


\section{Acknowledgements}

The authors would like to thank Katia Taela and Lúcio Posse for their helpful comments and suggestions at different stages of the research. We would also like to thank excellent research assistance from Andissene Andissene, Abudo Gimo, Ana Paula Meque, Domingos Saíte and Gaspar Tocoloa, and translation and data codification by Gerson Selemane and Muaziza Omar. To our interviewees and other residents of Cateme, Mualadzi, City of Nampula and Tete, we extend our thanks for their openness and the teachings. 


\section{Introduction}

In this paper, we explore the use of a governance diaries methodology to investigate poor households' interactions with authority in fragile, conflict and violence-affected settings (FCVAS) in Mozambique. The study is part of a broader research programme being implemented in Mozambique, Egypt, Myanmar, Nigeria, and Pakistan - Action for Empowerment and Accountability (A4EA), a five-year research programme (2016-21) which seeks to understand how social and political action can contribute to empowerment and accountability in FCVAS. In its initial phase (2016-18), ${ }^{1}$ the programme's research was divided into four sub-themes: Pathways to Accountability Bargains, Women's Social and Political Action, The Role of External Actors, and Meanings and Expressions of Empowerment and Accountability. ${ }^{2}$

The Governance Diaries Project was part of the Meanings and Expressions theme. The diaries aimed to understand the meanings of empowerment and accountability from the point of view of poor and marginalised people, with the aim of capturing what empowerment and accountability means for them, and how that changes over time, based on their experiences with governance. The study sought to record how poor and marginalised households view the multiple institutions that govern their lives; provide basic public goods and services, including health and security; and, in return, raise revenues to fund these services. The research questions included:

- How do chronically poor and marginalised households interact, access, and make claims on the different existing public authorities?

- How do they conceptualise public authorities?

- Do they feel (empowered, disempowered) when interacting with public authorities?

- How do they see/demand (bargain) accountability from different public authorities?

We combined observation with informal conversations and semi-structured interviews. We observed both 'the work of the state' 3 in the health, security, and taxation sectors within the communities we studied, and the environment in which our conversations and interviews with community members took place. We conducted these conversations and interviews with poor and marginalised

A4EA's second research phase started in 2019 and runs until 2021.

For more details about A4EA see the programme page on the IDS website.

Bierchenk and Sardan (2014) write about 'states at work' as a metaphor for emphasising two things: the incomplete nature of the state formation process, and its heterogeneity. Here, the expression 'the work of the state' refers to what the state does in practice; its 'daily' life. 
households, and local leaders and other actors identified by these households as being relevant to solving their daily problems. The interviews, conversations and observations took place in Tete, in the central region of Mozambique, and in Nampula in the north. We produced institutional maps with some households and leaders, with the aim of identifying the key actors in the health, security and taxation sectors and their power to solve governance problems.

Our findings show that, even if the perceptions and, with them, the concepts of empowerment and accountability that emerged in this study do not differ significantly from those identified in the literature, ${ }^{4}$ in terms of action and mobilisation there are distinctions. In Mualadzi, Cateme, Matundo, and Sansão Muthemba (Tete) and Khanloka, Namicopo, Mulu, and 7 de Abril (Nampula), people rarely mobilise to express their voice openly and collectively, even with prevalent injustices and poor basic service provision. Many claim to be 'unable' to influence or force 'authorities' to respond to their concerns and demands. By 'public authority', they understand any entity or person able to solve community problems, while the state, generally recognised as 'authority', is perceived as being similar to the Frelimo Party and the government, but it is also perceived as a father, although absent, and one who forgets and abandons his children.

This paper is composed of seven sections. Following this introduction, the next section briefly contextualises the study, focusing mainly on central features of the history and politics that have influenced the processes of empowerment and accountability in Mozambique. The third section details the project methodology, including the criteria for selecting the field sites and the households. The fourth and fifth present and discuss the findings, with the fourth focusing on the core state functions that we analysed as part of this project, namely health, security and taxation. The fifth analyses how and why people trust and confer legitimacy to certain key actors, and people's perceptions of public authority and the state. The sixth section continues with the theme of perceptions, and pays particular attention to the meanings and mechanisms of empowerment and accountability identified in the research. Finally, we draw a brief conclusion. 


\section{Country context}

'Weak state, strong party' is a key characteristic of present-day Mozambique (Sumich and Honwana 2007). Paradoxically, in Mozambique, the 'strong', which is the Frelimo Party, depends on the 'weak', which is the state. The state's weakness manifests itself in an inability to effectively deliver basic services to its citizens, including those of health and security, central to this research. The weakness also extends to the ability to collect revenues (Diaz 2014). According to World Bank data, ${ }^{5}$ in 2001 internal taxes accounted for only 12 per cent of Mozambique's gross domestic product (GDP); by 2020 it is estimated it will rise to just 19 per cent. The state's alternative is foreign aid, hence its dependency.

It is, however, from this poor and dependent state that Frelimo, in power since independence in 1975, extracts the resources through which it maintains its hegemony (Gentili 2005). ${ }^{6}$ This happens because Frelimo uses the state's meagre resources to feed its clientelistic networks, to control and co-opt citizens, to weaken the opposition, and to influence the media and other actors, including electoral bodies, creating what has been called a 'party-state' (Orre 2010). The origins of this Frelimo-state and, with it, political and social control, can be traced back to the period immediately following Mozambican independence in 1975, when Frelimo, at that time, the country's only political party, created 'Dynamising Groups' (DGs). From 1977 onwards, DGs transformed into local base structures. The functions of the DGs were: (1) to control the population, (2) disseminate party guidelines, (3) assist Frelimo leaders, especially in the Mozambican workplace, and (4) be channels for party participation (De Brito 2010).

In 1976, at the begining of the party-state structure deployment process, Renamo ${ }^{7}$ started a violent war against the Frelimo government. It advocated for a political and economic liberalisation (Hanlon 1991), as during the first republic (1975-90), Mozambique was, officially, a one-party state regime, with a centrally planned economy. The one-party state regime was officially abolished in 1990, with the establishment of Mozambique's first 'Democratic and Multiparty Constitution'. The new constitution reaffirmed the principles of freedom of expression, opinion and association (articles $74,75,76$ ), already recognised in a single article in the 1975 Constitution (article 27), but another important legal instrument was subsequently approved: the Law No. 9/91 gave the right to free assembly and demonstration. Both, the 1990 Constitution and the new laws,

See Mozambique profile, published by the World Bank.

Hegemony in the sense that, contrary to domination in which one party remains in power consecutively winning free and transparent elections (Carbone 2006), at least three times (Sartori 1976); Frelimo resorts to fraud and other mechanisms (Chaimite 2013).

Now the main opposition party, Renamo (Mozambique National Resistance) is a former rebel movement, which fought the Frelimo government in a brutal 16-year civil war (1976-92). 
created the legal and institutional framework for Mozambicans' greater participation in the politics of their country.

In 1992, Renamo and the government signed a General Peace Agreement (GPA), ending a war that for 16 years had gripped the country. This was followed by the first general elections in 1994. General elections were institutionalised and held regularly every five years, the same interval as between the municipal elections, introduced in 1998. Other initiatives, and with them spaces for participation, empowerment and accountability, subsequently gained momentum. Some examples include, watchdog initiatives, coordinated by civil society organisations, governance monitoring initiatives, participatory budgets, advisory councils and, more recently, open governance visits.

However, some of the initiatives and spaces mentioned above are manipulated and choreographed (Taela, Shankland and Awortwi 2016) by the party-state. Bottom-up initiatives (e.g. citizen marches and strikes), especially those that directly target or confront the authorities, are not tolerated and are sometimes repressed. The most permitted are provided spaces, ${ }^{8}$ subject to supervision and control by the party-state. These spaces are not, therefore, spaces of power in the sense of Arnstein (1969) and Gaventa (2005), where citizen participation is reflected in the decision-making process. In this context, it is worth asking: what specific forms do the processes and mechanisms of empowerment and accountability take? What does empowerment and accountability mean to the people in these locations? These are some of the questions that governance diaries have allowed us to study. 


\section{The Diaries}

The term 'Governance Diaries' is inspired by the book Portfolios of the Poor by Collins et al. (2009). In the 'Portfolios', the authors investigated specific and intimate aspects of people's daily lives, hence the term 'diaries'. They recorded in a diary the daily information of the people involved in their research, with a specific focus on financial issues. With the Governance Diaries, we went further; in addition to financial issues, we captured expressions and perceptions of empowerment, accountability, public authority, and the state. However, like the 'Portfolios', the Governance Diaries used deep, fine-grained observation and repeated visits and conversations.

\subsection{Methods $^{9}$}

\subsubsection{Locations and households selection}

Our methodological approach took into account the fragility of the state, described in the previous section, and the fact that the study sites are conflictaffected. We identified two types of conflict: conflict over land and armed struggle. In the first site, the conflict over land derives from contested resettlement in areas affected by the recent boom in natural resources in Mozambique. Coal mining is intense in the central province of Tete, specifically in Moatize District, and has led to extensive population resettlement. With households as our research units, we selected eleven in this province, six in Mualadzi village, where the people from Capanga (Tete City) are resettled, and five in Cateme Headquarters, inhabited by natives but with some resettled communities. Cateme Headquarters was a kind of 'control zone' since the communities in this village are predominantly 'at home', and therefore not directly conflict-affected.

Armed conflict is a feature of the second site, Nampula. In Nampula, a northern province, we selected Murrupula District because it was a major focus of armed attacks between 2013 and 2016, when Renamo resumed the armed struggle. ${ }^{10}$ In Murrupula, we selected six households in the village of Muliu, where most two decades the war resumed in 2013. This time, Renamo returned to the jungle after the failure of dialogue with the government, in which, among other issues, Renamo had argued for: (1) the need to separate Frelimo from the state apparatus, (2) the appointment of governors in almost all provinces in the central and northern regions of the country, where it claimed to have won the 2014 general elections, and (3) the integration of its guerrilla members into the Mozambican army and police. 
households who fled Napuco live. ${ }^{11}$ We selected six other households in 7 de Abril, a zone in Muliu. Like Cateme Headquarters in Tete Province, 7 de Abril was our control zone for Nampula.

We also took into account the rural-urban dimension, and therefore integrated the capital cities of both provinces within the research. For each of the capital cities, we identified two semi-urban neighbourhoods: Khanloca in Nampula, which is relatively distant from the centre of the city, and Namicopo, closer, but known for a high crime rate. In Tete, we selected Sansão Muthemba, on the right side of the Zambezi River, and Matundo on the left. We selected six households per neighbourhood, all based on the criteria of precariousness and poverty. By poor households, in this study, as in 'Portfolios', we understand:

Households that display evidence of deprivation of basic human needs that had existed over a long period of time (many months and often years) - chronic poverty. Examples include going hungry during the 'bad season', poor-quality housing, unemployment, lack of access to basic health services, children not attending school, and being socially outcast. Almost always such households have low and irregular incomes and few assets or negative assets because of indebtedness. The assessments of local key informants will help confirm that such households are poor or 'at the bottom end'. (Collins et al. 2008: 190-95)

Within the poor households, we looked for characteristics that increased their marginalisation, namely a mixture of being: female-headed; elderly and with no family support; religious minority; landless; displaced; at the lower end of the local social stratification system; cash transfer programme beneficiary; noncemented house; single earner in a menial occupation (or chronically unemployed).

We ended up with 47 households spread across the two provinces (Tete and Nampula), in four districts (Moatize, Murrupula, Tete and Nampula cities), and eight villages, zones or neighbourhoods (Mualadzi, Cateme Headquarters, Matundo, Sansão Muthemba, Muliu, 7 de Abril, Namicopo and Khanloca). There were six households in each village, zone or neighbourhood, with the exception of Cateme Headquarters, where we had just five, as one household dropped out.

At the time of the fieldwork, military and political tensions were still high, so it was dangerous to move our teams to Napuco, where the Renamo military base is located. We chose to work in Muliu as it is close to Napuco and holds most of the households from that village. 


\subsubsection{Data collection and analysis}

The research was based on monthly open and systematic conversations with the 47 poor and marginalised households described above, semi-structured interviews, especially with local leaders and other stakeholders identified by the households as being relevant to solving their daily problems, and observation. We observed all the details of the locations where our conversations and interviews took place (e.g. under a tree, inside a house, the type of house), and aspects related to the interviewees (e.g. their physical appearance, language used and tone of voice). In some cases, we also observed the functioning of some of the institutions that provided the basic services that we analysed, especially health.

From the fourth round of conversations with the households onwards, ${ }^{12}$ we introduced institutional maps. The aim was to identify the main actors concerned with particular issues, their power to solve problems, and how the households access (or not) these actors. Part of the exercise was to 'interview the diagram' (ask questions about what is represented in the graphic), to probe how and why participants chose to identify certain actors, which criteria they use to determine power, and the level of relationship between different actors. The final aim of the exercise was to see who different households identify as public authorities, and the reasons why they do so.

\section{Figure 3.1 Example of institutional map design health issues}

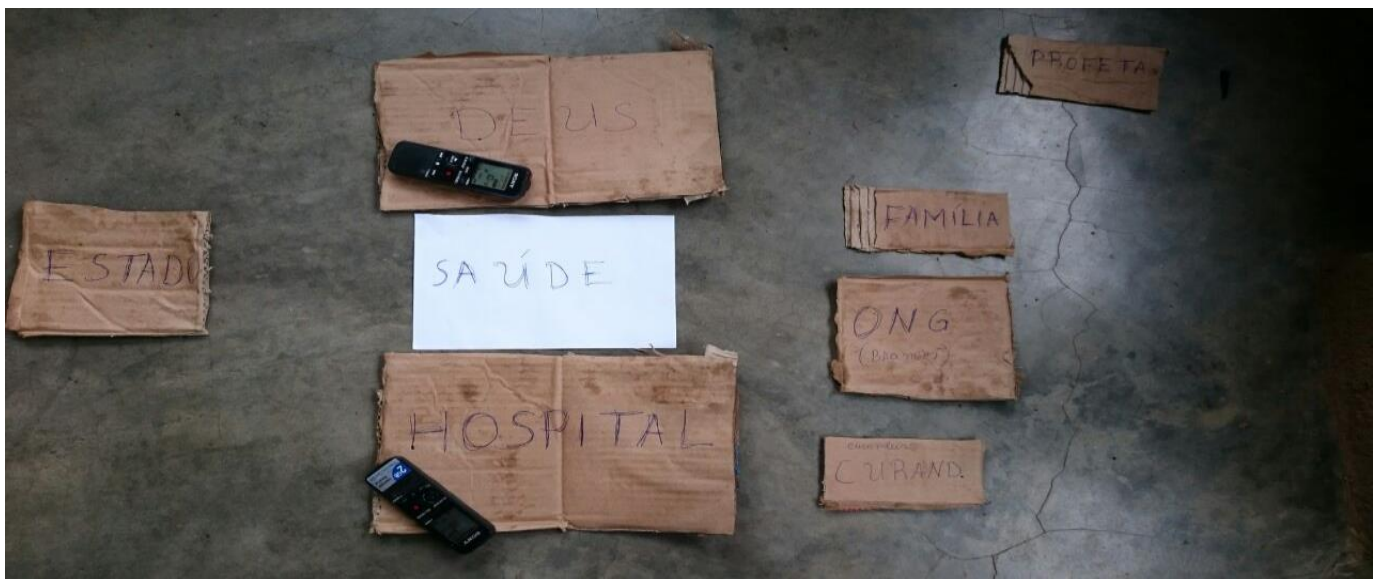

Nampula, 29 October 2018. Source: Research Team 


\section{Figure 3.2 Drafting institutional map on household income}

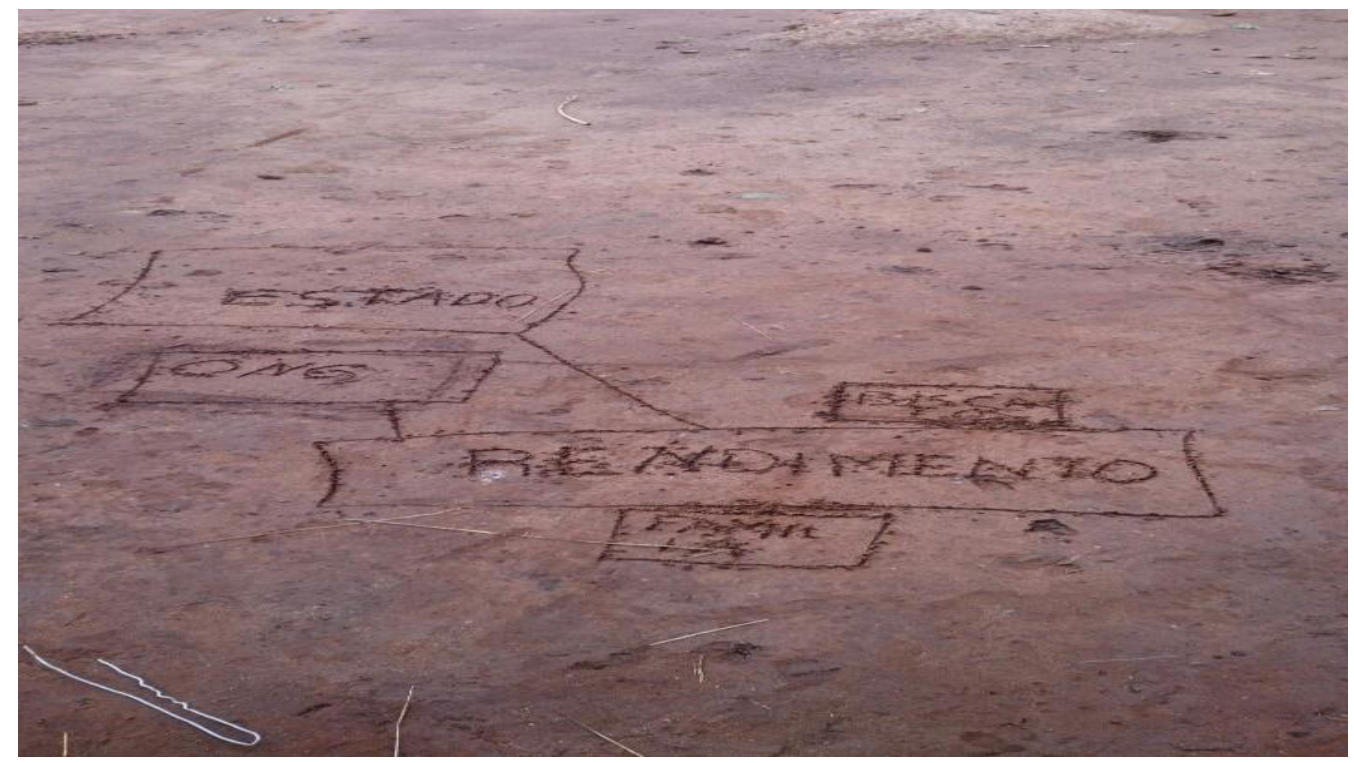

Tete, 20 September 2018. Source: Research Team

For each conversation, interview, and simultaneous observation, we produced descriptive and reflective field notes. Descriptive field notes are detailed and accurate descriptions of what the researchers saw, heard, and experienced. The researchers described with as much detail as possible, accounts of particular events and actions, including listing who was involved, what the event was, how participants were involved, the nature of their actions, historical details that could provide context for the event, and so on. This was important because events, activities, and particular actions of respondents in any setting reveal how they live their lives and the meanings they attribute to the behaviours implied by those actions.

Reflective field notes were personal accounts of what researchers were learning, including their speculations, feelings, problems, ideas, hunches, impressions, prejudices, analyses, plans for future inquiry, clarifications, syntheses, connections, and other ideas about each inquiry. While descriptive field notes gave us helpful insights about the value and nature of the events in respondents' lives, reflective field notes provided the contextual framework for interpreting the descriptive field notes, thus complementing each other.

Data analysis was a monthly task, as we revisited all word transcripts we coded manually, whenever we received our field notes. During this process, we identified trends and readjusted the research methodology. In short, it was an iterative process. ${ }^{13}$ 


\section{Accessing services}

The ability to provide basic public services is key to understanding the concept of 'fragile state', 'fragile context', or 'fragile setting'. A fragile state is commonly understood as one being incapable of guaranteeing minimum security conditions, and providing other basic services (e.g. health and education), as well as economic opportunities for its citizens (Mcloughlin with Idris 2016). However, as Green (2017) notes, this concept is contested because it does not take into account all the different facets of fragility, identifiable in almost all states, while, at the same time, few states are completely fragile.

In the case of Mozambique, taking into consideration the aspects mentioned in section 2, we consider that the term 'fragile state' is applicable, but in this paper, following Green (2017), we use the term 'fragile contexts' or 'fragile settings', because, in fact, in some of our study sites, fragility is much more pronounced than in others. We hypothesised that, in these contexts, resettlement and armed violence as presented in the previous section, worsen the marginality and fragility of the selected households. Is this the case? In these contexts, how do people go about solving their governance problems? Who are the actors they turn to? Why? We focus on three core state sectors: health, security, and taxation.

\subsection{Health}

From our first monthly visits we noted that every family had experienced some kind of health issue, whether in their household or in their neighbourhood. To solve these, they had resorted to both hospitals and health centres (available in all four locations) as well as traditional healers. The services provided by healers are much more expensive than those of hospitals, but people place most trust in them to solve their health problems. However, going to healers is often preceded by going to health centres or hospitals, but when this did not happen in some places, such as in Muliu in Murrupula, the healers themselves had advised their patients to go first to hospital and after that to approach them. Among the explanations for the healers' recommendation is the need to ensure a better diagnosis of the disease, since hospitals have the most effective diagnostic tools, in addition to reinforcing healers' legitimacy, after the alleged failure of hospital treatments. With enhanced legitimacy, healers can set higher prices: 
Question (Q): They said that you accompanied your sister to the healer, how much did you pay?

Respondent 2 (R2-head of the household): ... for them to guess [my illness], I paid 20 meticals. For treatment, 60 meticals and, in total, it was 80 meticals. $^{14}$

Q: And that hand, when you got sick, did you go to the hospital?

R2: Yes, I did. They analysed it, but they found nothing.

$\mathrm{Q}$ : But did they prescribe anything?

R2: I paid 1 metical for consultation and 5 meticals for medicines.

Q: Out of those two issues, did anyone else get sick?

R1 (mother): Just my daughter. She had thrombosis.

R3 (daughter): I first had thrombosis. After a month, was I attacked by dysentery, that same December.

$\mathrm{Q}$ : Where did you go to cure dysentery?

R3: I did not go to the hospital. I took these traditional medicines. I did not go to the healer either. I just took some leaves and God helped me, because I was healed.

(Interview, Household 1, Nampula, Namicopo, December 2017)

The above excerpt is from a conversation giving indicative data on the costs incurred by households in referring to each of the two key health sector actors: hospitals or health centres and healers. It also shows how the lack of financial means block access to that basic service, despite the relatively low costs from either health sector actor. Some households do not resort to any treatment, simply because they cannot afford to pay for it. They end up staying at home, suffering from disease, as we witnessed in almost all the families we visited. They claim they have no money for the consultations, nor to buy medicines.

Apart from the cost and lack of medicines, complaints around the health sector also included the issue of late opening, and nurse or doctor refusal to attend patients, especially on weekends and evenings. In Mualadzi (Tete Province), households complained a lot about poor service, with cases of women delivering babies on hospital balconies, because of the alleged negligence of the hospital staff. These situations also contribute to households resorting to traditional healers, who, as we note above, they most rely on to solve health problems, even though they are much more expensive than hospitals and health centres. 


\subsection{Security and justice}

Traditionally, security is a responsibility assigned to states (Del Rosso Jr. 1995; Hama 2017). This is because security:

has long (though not exclusively) meant 'protection from organized violence caused by armed foreigners'. Since 'foreign' implies a person who is 'not like us,' and since territorially-based states (or nation-states) emerged in Europe after 1648 as the dominant organizing principle for separating 'us from them', security's identification with the state is not surprising.

(Del Rosso Jr. 1995: 183)

As Del Rosso Jr. explains, 'the state became not only the chief provider of security, but also its chief interpreter' because the bureaucracy consolidation process, and with it that of the state itself, resulted largely from the consolidation of the state's military capabilities. For Hama (2017), however, in addition to state security, there is also society and human security, which highlights the importance of other actors. If we add justice to security, as we do in this study, who are the actors who stand out? What kind of security and justice are we talking about?

In our research, (in)security is internal and, basically, twofold: on the one hand it is about armed conflict, and on the other it is associated with crime, which, to different degrees, occurs in almost all our fieldwork sites, with more intensity in Namicopo, on the periphery of Nampula city. In the case of armed conflict, we interviewed households from Muliu (Murrupula), some of whom came from Napuco where there is an important Renamo military base, and, therefore, is one of the main foci of military confrontations in Nampula. Despite the break in attacks in Napuco, some of the households coming from this village preferred to remain in Muliu, as, they said the presence of soldiers in Napuco continues to endanger their lives. However, many of these families say that leaving Napuco increased the precariousness of their lives, since they had their lands there on which they grew crops, their base of subsistence. With few alternatives, many continue to go to Napuco to farm, but always return to Muliu where they feel more secure. It should be noted that Napuco has relatively more fertile lands than those in many areas of Murrupula, including Muliu, hence the households continue to take these risks:

Here [in Muliu] I look like a refugee. I have no land... Where I cultivate, they lent me and I live through it. But it's hard here... even when there were still many shots in Napuco, we [from the household and neighbours] still went to Napuco because we produce more 
there than here... we just farm and return here to sleep. Even now I do not go back to live in Napuco because l'm used to stay here... [moreover], we also do not know when the [shots] will start again. They do not inform. I prefer to stay here, but I will continue with my lands there in Napuco...

(Interview, Household 3, Nampula, Muliu, November 2017)

In terms of crime, Namicopo stands out. The neighbourhood is considered a 'neighbourhood of bandits' and there is a term used in Nampula to designate the bandits: anamicopo, which literally means 'from Namicopo'. An elderly woman told us that if, for example, there is any confusion in a queue in hospitals and they realise that there is someone from Namicopo, they say 'that one from Namicopo is the troublemaker!' (interview, A.M., Nampula, Namicopo, October 2017). With respect to medical treatment, according to the elderly woman, when someone from Namicopo has a limb injury (often caused by a motorcycle accident), the response tends to be radical: they cut off the arm or leg. Although some inhabitants of the neighbourhood are accustomed to the criminality and the stigmatisation to which they are subject, others avoid identifying themselves as being from Namicopo in order to avoid discrimination, especially in accessing public services such as health:

As for thieves, here is their home. That is, here is their own zone.

Even there in the city it is already known that all people from Namicopo are bandits. So when someone goes to the hospital, for example, [they] cannot say that [they are] from the Namicopo because he will not be treated as we are seen as criminals and unruly.

(Interview, Household 1, Nampula, Namicopo, September 2017)

In many of the interviews, household members from Namicopo indicated they knew the criminals as, they said, '... they are our children here in the area... (Interview, Household 3, Nampula, Namicopo, January 2018), although, in some circumstances, they associate crime rates with the presence of people from other provinces, especially Zambézia, in the central region of the country, and known to be the stronghold of Renamo. However, even if they know the criminals, and denounce them to the police and the ward secretaries, few believe either, or, both together, can stop crime. '... Thieves appeared and robbed doors and 18 bars, but the owners preferred not to complain because they just thank and trust Allah as they are Muslims', said one of the interviewees (Interview, Household 1, Nampula, Namicopo, September 2017).

As in Namicopo, in Khanloka (Nampula), and Sansão Muthemba and Matundo (Tete), households resort to the police and ward secretaries if they have a security issue. In Cateme Headquarters (Tete), however, they resort to the village chiefs, while in Mualadzi (Tete) they also turn to the Natural Resources 
Management and Development Committee, a community-based organisation. Only if the chiefs or committee cannot solve or help solve the problem in these villages, do the households go to the police. In the case of Mualadzi, thanks to the dynamism of the committee, if the problem is still unresolved, it moves up the hierarchy, starting with the local leadership, until, if necessary, reaching the district level. However, cost hinders access to justice. According to several households in Mualadzi, in the case of litigation, robbery, or any other situation that requires the intervention of local leadership, they are illegally charged money which many families cannot afford. A similar situation was noted in Namicopo:

$\mathrm{R}$ : I do know is that when someone has a problem and complains, the one who complains pays and the accused also pays.

Q: How much do they pay?

$R$ : The one who complains pays 50 meticals and the accused 50 meticals.

$\mathrm{Q}$ : Why does the complainer have to pay?

R: I do not know.

$\mathrm{Q}$ : Why is not just the accused paying?

$\mathrm{R}$ : Who should pay is the accused, but here everyone loses, both the accused and the complainer pay.

(Interview, Household 4, Nampula, Namicopo, January 2017)

There is, however, a curious situation in Mualadzi, where for security issues, besides resorting to the committee, people have to go to the police commander's house rather than the police station, which is normally abandoned. According to the commander himself, he prefers to work at home because there are almost never any criminal cases and the community know where to find him. Our interviewees from Mualadzi, however, complained of students who go to Cateme to attend classes experiencing robberies which makes them give up school.

Thus, up to this section, it is worth noting that both state and non-state actors are important and some are recognised as authorities in the exercise of important governance functions, such as the provision of health and safety services. Some of the non-state actors are the first interlocutors for households because they are perceived as being linked to the state, even if they are not, at least not directly, for example the Natural Resources Management and Development Committee in Mualadzi.

\subsection{Taxation}

Taxation, a core governance function, greatly influences state-society relations (Brautigam et al. 2008). Indeed, tax revenues do not only allow states to provide security and public goods (ibid.), but the entire taxation process can play a democratic role (Kato and Tanaka 2019; Dom 2018). This is because tax payers should monitor the use of their money, which, at least in theory, generates a 
democratic due from the state (Kato and Tanaka 2019; Dom 2018). 'No taxation without representation' is the expression of this relationship, meaning that, without representation, and, therefore, the right to participate, decide and supervise, there is no obligation to pay taxes. It is a matter of rights and duties, central to democracies. But in contexts of marginalisation and poverty, how is tax perceived? Who pays what kind of taxes and why?

Without income, citizens cannot pay taxes, at least in cash. For this reason, in this project we started by inquiring about our study households' income and the source of this income. We found that in all locations, it was difficult for households to estimate their monthly income, since, on the one hand, most household members do not have permanent employment and, thus a regular source of income, and on the other, the majority basically survive off subsistence agriculture. Those living in the cities, who also practice subsistence agriculture, resort to majorijo (odd jobs) and small informal businesses such as selling water and drinks.

In regard to official taxes, few of the households we interviewed pay. Women, in particular, simply do not pay and, moreover, few of those interviewed, in both rural and urban settings, knew what the taxes were used for. ${ }^{15}$ One example is shown below from Khanloca in Nampula:

Q: Do you pay taxes?

R: No. I do not.

Q: But have you ever paid taxes?

R: No, I have never paid because I have never heard of women

paying taxes. Since colonial times women do not pay.

$\mathrm{Q}$ : But do you know where taxes are paid?

R: I no longer see people looking to know where they are paid.

$\mathrm{Q}$ : But do you know where they are paid?

R: I used to hear people talk about that, not now.

$\mathrm{Q}$ : What did you hear?

R: I heard people saying that they had paid at the Matador Post.

$\mathrm{Q}$ : How much did these people say they paid and to whom?

R: I only heard people saying, but I do not know how much they paid.

$\mathrm{Q}$ : Did not these people say how much and what they paid?

R: No, but it has been a long time, and I have never asked how

much and what they paid. I just heard them...

Q: Did you just hear?

R: Yes, I just heard about it.

(Interview, Household 1, Nampula, Khanloca, September 2017) 
Mualadzi is an unusual case. In this village neither men nor women pay, despite knowing the usefulness of taxes. According to them, they do not pay simply because they cannot afford to do so, since they are impoverished by resettlement. One of the interviewees asked: 'who will have the courage to come here and tax us, after what they have done to us?' (Interview, D.S, Tete, Mualadzi, September 2017), referring to their precariousness caused by resettlement. The issue of precariousness and poverty was also raised in the peri-urban areas of both Nampula and Tete as the reason for not paying taxes. The following excerpt, which is from a conversation held in Matundo, Tete, is just one example:

Q: Have you ever heard of tax?

R: Yes I have. Now if you want to know if I pay, the answer is no.

$\mathrm{Q}$ : Why is the answer no?

R: If I do not have the money to buy food, how will I have for taxes?

(Interview, Household 2, Tete, Matundo, September 2018)

However, on a small scale, we noted that, in addition to the fees charged at daily fairs and markets, in Murrupula some households pay for a licence for bicycles and what they called a bicycle tax, on an annual basis. According to the village chief in Cateme Headquarters, there is also a household tax, which the local leaders expected to be doubled, but, because of poverty in the area it was instead reduced. According to the village chief, even with the reduction, few pay.

Those who pay do so, as they say, 'to avoid getting in trouble with the authorities' (Interview, Household 1, Nampula, Murrupula, September 2017), but not because they know how the money is used, or where their contributions go. They do not even ask: 'They do not say.... They (the chiefs) are the ones who know, but they never say the utility of [the] money' (Interview, Household 3, Tete, Matundo, September 2017). As for enforcement, it seems more effective in rural areas, where village chiefs are more significant figures. It is these chiefs who collect the taxes and who oblige people to show their tax receipts if they need intermediation to solve a problem and/or access state services. Without the tax receipt, households are not attended to. In the peri-urban areas, this task is carried out by the ward secretaries, but as in the rural areas, given their precariousness and poverty, some households are unable to pay.

Thus, because of precarity, aggravated by armed conflict and resettlement, few households have money to pay taxes. Others simply do not pay because, as they say, they do not understand why they must pay. In Mualadzi, non-payment is a form of protest for the alleged forced resettlement, which was also, according to the households, poorly organised. In addition, for lack of money, households find it difficult to access services from either the state or non-state actors. However, the fact that household members sometimes resort to nonstate actors to access services traditionally provided by the state, shows that the 
state does not play an exclusive role in performing governance functions. As Green notes (2017: 9), ' $\ldots$ states are not the only institutions responding to citizens' needs...' and the task of organising collective action to create public goods may be shared between a great variety of actors. Who are they? We now turn to those identified by our interviewees. 


\section{5. 'Who can we count on?' Trust, legitimacy, public authority, and state}

To count on entities or individuals, one needs to trust them and, in some cases, recognise their legitimacy. But how is public authority defined? And legitimacy, what is it? What gives legitimacy to actors in resolving the governance issues we focus on: health, security and justice and tax? In this section we explore the perceptions of the households we surveyed on these issues.

\subsection{Legitimacy and trust}

The question 'what is legitimacy?' is often preceded by another, which is: 'legitimacy to do what?' (Bakarat et al. 2016). In this study, the answer is: legitimacy to address governance issues, usually entrusted to states (Englebert 2002; Hutchison and Johnson 2011), but not exclusively, as they are also attributions of non-state actors (Risse and Stollenwerk 2018; Lake and Farris 2014). As Risse and Stollenwerk (2018: 407) put it, '... the state is only one governor among many in areas of limited statehood and... external and nonstate actors, such as NGOs, multinational companies, and IOs, are as relevant for governance.'

Risse and Stollenwerk (2018) distinguish, then, three types of legitimacy: normative, legal, and empirical: normative and legal legitimacy assess whether certain actors or institutions have the right to govern, based, respectively, on issues of beliefs and existing laws. Empirical legitimacy is ' ... a given population's sense of obligation or willingness to accept [governance actors] authority' (ibid.: 404).

In this paper, we adhere to Risse and Stollenwerk's approach to legitimacy, but we also adopt a broader perspective, combining elements of all three types, as we found in our research. This broader perspective recognises the importance of both acceptance, as for Risse and Stollenwerk (2018), Ivison (2017), Habermas (1997) and Luhmann (1980), and consensus on a specific subject with which the entity or individual deals (Rawls 1993). We start with the sources of legitimacy.

Based on the above perspective, we identified two sources of legitimacy: (1) legitimacy conferred from a hierarchical position to actors in the communities by other entities to whom, for different reasons, power is recognised by members of the communities (e.g. the Frelimo Party or the state), and (2) legitimacy conferred horizontally by community members on certain actors, not necessarily 
associated with other entities considered 'superior'. We can illustrate the first case with the following extract:

Yes, we pay taxes to the ward secretary because he is the one who was put to do that job. He works with those from the party (Frelimo), from the locality and even district level. They used to come here... [so] we know him and he goes there to his bosses... (Interview, Household 1, Nampula, Murrupula, September 2017)

The ward secretaries are interesting actors when it comes to addressing governance issues at the local level. Generally, they are recognised as important and, therefore, legitimate, precisely because they work with the party or the state, but for people to go to them, they have to be perceived as valid interlocutors in solving community problems. When there is no trust in them, or in other local leaders, as in Mualadzi, the communities legitimise other actors. This is how Mualadzi Natural Resources Management and Development Committee emerged as an alternative and, thus, legitimate interlocutor in solving daily problems, including those related to health and security. This highlights the issue of trust as an element associated with legitimacy. As Gastil (2000) puts it, without trust, the legitimacy of any institution can be called into question.

As we showed in section 4, the prominence of some actors results from the confidence placed in them by households. In the case of health, for example, on the one hand, there is relative trust placed in hospitals and health centres, but on the other, in terms of effectiveness, healers stand out. On the issue of security, police action is generally not considered trustworthy, but in Namicopo even ward secretaries are not trusted. Some citizens say they 'get by' and others that they simply 'leave it to God', as shown in section 4. For taxes, the image of ward secretaries is little different than that of the village chiefs, although neither explain the usefulness or destination of taxes, they are not questioned by communities. Again, Mualadzi households are an exception here, thanks to the dynamism of the Natural Resources Management and Development Committee, however many of these households said they did not pay tax due to poverty or in protest.

\subsection{Public authority}

A common perception amongst the respondents is that public authorities are entities that solve or help solve different governance issues, especially when the authorities are seen as associated with the party-state. With some nuances, this definition is in line with how Unsworth (2010) conceptualises public authority. Unsworth defines public authorities as including formal and informal institutions, 
... can undertake core governance functions: protection from external threats, and managing external relations; peaceful resolution of internal conflicts; and providing or facilitating the provision of a range of collective goods and services.

(Unsworth 2010: 9)

The merit of this definition is in pointing out the importance of a diversity of actors in any governance function, including non-state actors. In the previous section, we identified healers, civil society organisations, police officers, village chiefs, and ward secretaries as public authority figures. Alexander (1997) has previously shown that these actors are authorities in local Mozambican contexts, especially healers and village chiefs. Alexander also refers to a crisis of authority in the country:

The Mozambican state, and Mozambican society more widely, is experiencing a profound crisis of authority. The nature of the crisis is rooted in the practices and pressures of previous years. It is a product of the post independence state's failure fully to transform Portuguese notions of authority, its coerciveness and militarisation, its blurring of distinctions between state and party, attacks on spiritual authority, and inability to deliver or protect economic progress.

(Alexander 1997: 20)

From our study, a key figure for village and neighbourhood authority is the police. Police officers always introduce themselves as being 'authorities' or even chiefs, and are treated as such, both in rural and urban areas. Like the term 'authority', locally, the term 'chief' is associated with the exercise of some function within government, or the state, unlike the ward secretaries, who are clearly party figures. However, in practice, given the political context described in the first section, these figures overlap and the chief is more partisan, although, officially, included within the administrative structure of the state. However, both figures are widely referenced as authorities within our different research sites, although the ward secretaries stand out more in urban areas and the village chiefs in the rural ones. In Muliu, for example, the village chief is the figure people most often rely on to solve their problems, hence seen as the authority, at least for those communities. In a similar way, the ward secretary is quite often referenced in Khanloka (Nampula) and Matundo (Tete).

However, overlaps in the representation of authority and leadership sometimes lead to confusion. In this context, 'authority' often appears as the one who directs, 'helps, guides, advises' (Interview, Household 7, Tete, Cateme Sede, December 2017), in addition to solving community problems. An authority is, 
everyone who is responsible for something. For example, the chief and ward secretaries are authorities and watch over our existence. They care about our problems and fight for these problems to be overcome being mediators. They can decide on whatever. They decide who to choose to do a certain activity. They choose people they want and think can... so they can, for example, receive the money of the elderly. All this because they are authority and have power... (Interview, Household 1, Nampula, Namicopo, October 2017)

Thus, from the different interviews and conversations, we noted that authority presupposes the existence of some legitimacy, even if there is no trust. In Namicopo, for example, there is no trust in the effectiveness of the police and ward secretaries in dealing with crime, but they are recognised, and therefore are seen as legitimate authorities. Conversely, in Mualadzi, the ward secretaries and other local leaders (ward secretaries and traditional leaders) are neither trusted nor recognised or accepted, as they are perceived as unable to solve local governance issues, and so are not seen as legitimate in the eyes of the community. In Mualadzi, the Natural Resources Management and Development Committee stands out as the alternative legitimate 'authority'.

\subsection{State}

There is an extensive literature on the Mozambican state (e.g. De Brito 1991; Gentili 2005; Carbone 2006). For much of this literature though the state is defined as simply a 'party-state' (e.g. Orre 2010; Nuvunga 2014), thus not distinguishing it from the government. According to Bertelsen (2016: 9), 'what we normally define as the state is for Mozambicans frequently referred to as o Estado (the state), o governo (the government), o partido (the party, i.e. Frelimo), or simply as just Frelimo (the Frelimo party)'.

In this study as in the literature, the terms 'state', 'party', and 'government' are used interchangeably, and the local actors evoked when speaking of any of these entities are the same: village chiefs and ward secretaries, the latter being specifically partisan:

Government are chiefs and ward secretaries. These are government (sic) and they held a meeting saying to go back to Napuco because the war is over. The government is the state that sends and helps us... (Interview, Household 6, Tete, Cateme Sede, August 2017)

In terms of expectations, however, there are points to note. The state is perceived as a father and, as such, people expect it to, 'guide', 'command' and 'help' them. They hope that the 'father' provides basic services and acts as an authority, solving community problems. That is why they always resort to it: "because everything we have or need we go to the state. Even prisoners go to 
the state. The state regulates people's behaviour and the way they live' (Interview, Household 2, Tete, Matundo, January 2018).

However, because the state, and with it the government and the Frelimo Party, are evaluated by the services they provide, and these being precarious or not provided, not even the physical proximity of the identified representatives (village chiefs and ward secretaries) renders the father present:

R: We feel that the government betrayed us. Everything is expensive. It is hard. The big problem is hunger and there is no job for the youth. The government does not want us.

$\mathrm{Q}$ : Why do you say that?

$\mathrm{R}$ : We are discriminated against. They gave better conditions to the next ones [the resettled]. Our problems are solved by the resettled... where have we seen this? We lost our authority.

Q: But why do you say that you have lost your authority?

$R$ : Because we received them [the resettled]... but they are the ones who command us here now.

(Interview, Household 6, Tete, Cateme Sede, August 2017)

The above extract also reveals cleavages between the existing residents of Cateme Headquarters and the resettled households, around service issues, which are seen as relatively better for the resettled community. However, the image of state as father, not only absent, but also as having forgotten them, also extends to other locations. This excerpt is from an interview in Mualadzi: 'State are people who protect us. They give us schools, hospitals, police, highway... But we are losing our hope on this state because it is forgetting us' (Interview, Household 4, Tete, Mualadzi, December 2017).

The state 'is forgetting' because, in the imaginary of the people we interviewed, it does not provide basic services, or, when it does, they are inefficient. This does not meet the expectations people have of a father, which the state has always presented itself as since the one-party era began. However, even defrauding expectations which undermines people's trust in it, the state's legitimacy in the community is still rarely called into question. The Mualadzi case presented above is an exception. But even in the Mualadzi case, it is just the local leaders - the village chiefs and ward secretaries - identified as the state, who are not trusted nor recognised as legitimate. The figures above them, especially at the provincial level, are still respected and recognised:

The problem is with our local leaders. Some do not do their job. [We] put the concerns, but they never solve it... others are just there to eat... because the higher levels [central and provincial governments] send things [money and other material]. Our chiefs and leaders do not respect us. They eat.... That's why I say that higher levels are 
better. They help, but here [at the bottom] there are problems.

(Interview, Household 3, Nampula, 7 de Abril, January 2019)

In summary, in this study, none of the interviewees devalued state authority. However, the state is identified and evaluated mainly through local actors (e.g. ward secretaries and village chiefs), and it is these local actors who are considered relatively less able to solve community problems, at least in comparison to those at higher levels (e.g. provincial and central government). It is not only a matter of physical proximity and the consequent trivialisation of the image of local actors whom the interviewees often know personally as they live with them on a daily basis, but it is, and perhaps above all, an assessment of the conditions, including materials, which are noticeably less available at the local level. It is here where the other actors emerge. They are those who, by proving able to intercede at other levels and mobilise other resources, can solve or help to solve various community problems, thus emerging as new public authorities. This is the case with the Mualadzi Natural Resources Management and Development Committee.

\section{Box 5.1 The Mualadzi Natural Resources Management and Development Committee}

The Mualadzi Natural Resources Management and Development Committee, known locally as simply 'the committee', is a community-based organisation established in 2014 by a group of resettled people in Mualadzi village, in Moatize District, Tete Province. It currently consists of 150 members: 100 women and 50 men, all living in Mualadzi.

Its members pay 20 meticals monthly, but the committee also has the financial support of other national organisations based in Maputo. The Associação de Apoio e Assistência Jurídica as comunidades (AJC) is just one example. According to one of the leaders of the committee, it is with the financial support of AJC that they pay rents, water and electricity, so for that leader, 'AJC is like a mother'. Sekelekane, another organisation also based in Maputo, help the committee with office supplies.

The committee also collaborates with various international organisations such as the World Wide Fund for Nature and Oxfam. With their support, the committee works mainly in the areas of extractive industry and legal assistance. However, in the community, they became intermediaries, solving or helping to solve a wide range of problems. 


\section{Box 5.1 (cont'd.)}

The following is an account of some of the issues and how the committee attempts to solve them:

The committee is doing a great job. We managed to establish dialogue at the highest level. We are talking with the provincial government, but with the [local] leaders... you already know our differences. It all started because of a complaint we made to the Governor. We told him about the absence of teachers at schools and poor care in hospitals. We set up a [public] meeting and called the leaders, but they just didn't show up. We talked to the head of the locality, the head of the hospital himself, the school director... [they] recognised. The school director said that the absence of some [teachers] was because they were busy preparing some official documents and others... We waited, but the problem continued, and was getting even worse. So, we wrote a letter to the Administrator. We reported the anarchy in the health centre... Again, we waited for about a year, but we had no reply. In October or November, we went up the hierarchy, contacting the Governor himself... He sent a commission to inquire. They found that we were right: there were problems in the health and education sectors. As a corollary of this, the school director was replaced, his deputy transferred, but in the health centre there were no changes...

This extract continues with reports of how the committee proceeded to ensure that the community had access to transport, energy, water, security and justice services. It goes on addressing the issue of their conflict with local leaders, which, according to our interlocutor, led them to open the committee, which in fact resulted from the revitalisation of another committee. The other had been comprised of some community members, but was led by local leaders, including traditional leaders and the neighbourhood secretaries, in addition to Frelimo members. Because of disagreements with those leaders, as, according to our interviewee, '... they seemed to be working more for the mining companies and themselves than for the community', members of what became the Mualadzi Natural Resources Management and Development Committee decided to leave. They started as a group of ten people then others joined them. However, after five years, and despite many attempts, the committee is not yet legalised and still works as an informal organisation. 


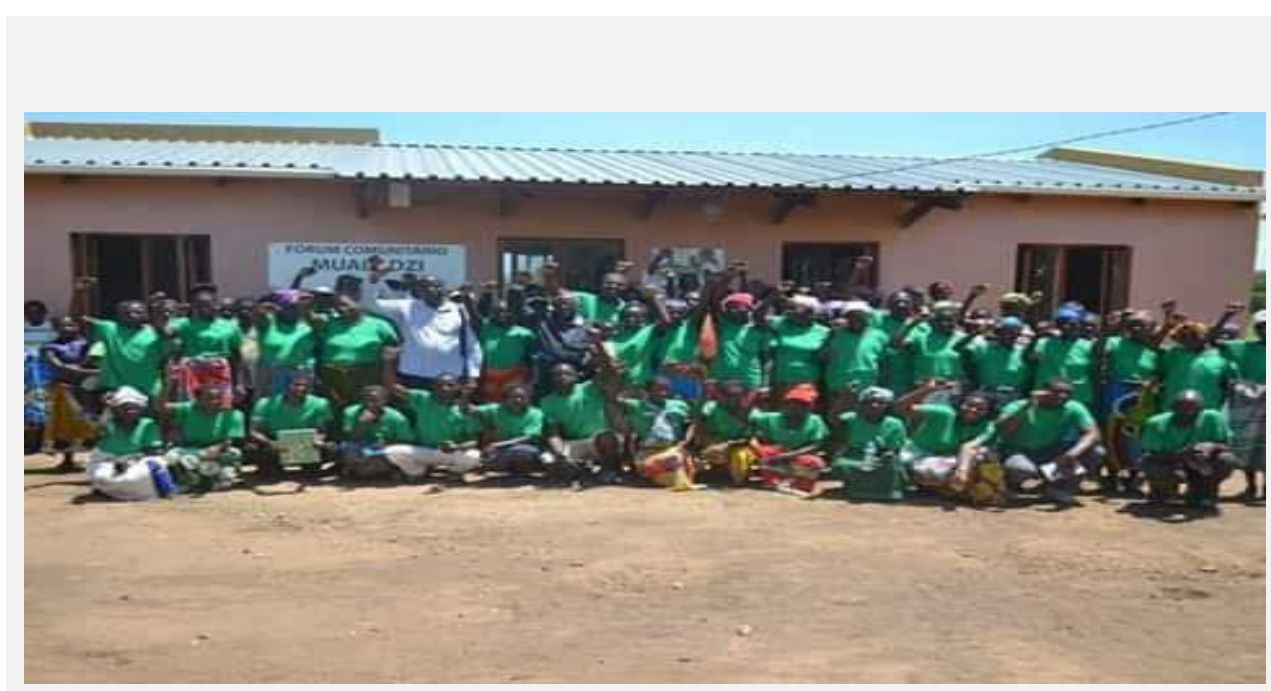

Committee members after a meeting, May 2019

Photo: @ Research Team 


\section{Empowerment and accountability}

After identifying the actors 'to count on' to solve the daily problems of the households we interviewed, in addition to the perceptions of their legitimacy and/or identification as authorities, we now address the perceptions and expressions of empowerment and accountability. The central questions are: (1) Do people find their encounters with public authority empowering? (2) What does empowerment mean in these contexts? (3) Are public authority actors responsive and what makes them so? (4) What is accountability to poor and marginalised people?

\subsection{Empowerment}

Empowerment is both a process and an outcome (Luttrell and Quiroz 2009). It is a process of individual and group emancipation (SDC 2004; Cornwall and Edwards 2010) from disadvantageous situations (DFID 2011; SDC 2004), gaining (greater) control over resources and 'power sources' (Batliwala 1994; Sen 1997), whether political, economic or cultural (Luttrell and Quiroz 2009; Piron and Watkins 2004). The result of this greater control: more consciousness, more ability to make choices and, above all, exercise rights, including participating in decision-making processes (Alsop 2004; Cornwall and Brock 2005; Cornwall and Edwards 2010). However, in FCVAS, these processes are rare, risky and have unpredictable outcomes (Loureiro et al. 2020) as we found in our research, but with some peculiarities.

We found that feelings of disempowerment, expressed by terms such as 'disability', 'resignation', 'detachment' and 'exclusion', are predominant. Our respondents are almost unanimous that when there is no response to community requests, when they 'do not do what we asked for' (Interview, Household 1, Nampula, Murrupula, January 2018), there is no respect, no consideration and no inclusion, hence disempowerment:

$\mathrm{Q}:$... do you guys make any decisions about the next steps?

$\mathrm{R}$ : We are alone. No one helps us, since we have no power with words. We cannot determine anything. In other countries or provinces, there is help. People speak, have the right to speak, they offer plastics and straw, but we do not receive any help... We are hiding. Other times we manage to get things out of our Machambas ${ }^{16}$ to survive, but this time everything was lost... (Interview, Household 1, Nampula, Murrupula, January 2018) 
Empowerment, which appears in terms such as 'learning', 'knowing', 'being heard', 'respected' and 'included', occurs when there are (perceptions of) response to community requests, when they 'do what we asked for' (Interview, Household 1, Nampula, Murrupula, January 2018). Under these circumstances, people feel 'respected', 'considered', 'included', and therefore 'empowered':

When people have concerns, they [the leaders] gather and they go to their chiefs to present them... The chief listens and writes down what the community say and he [the chief] takes them to the administrative post. Then the administrative post takes the concerns to Murrupula [district], then, from Murrupula, to Nampula [province]. Later, we are given orders, guidance and we have our response... We feel good, because they listen to us.

(Interview, Household 12, Nampula, Murrupula, January 2018)

The excerpt above, from the interview with household 1 in Nampula, shows a feeling of 'lack of rights', but also of resignation and that they just 'get by', because they have no power, and, thus, no means to obtain concessions from the authorities, entities with which they need to interact in order to develop feelings of empowerment. This relational dimension is highlighted by Batliwala (1994: 120): 'empowerment is the process of challenging existing power relations'.

A few gender issues also emerge from households' interactions with public authority. For instance, in order to 'be capable', women consider it necessary to have an intermediator - their husbands - because, despite their attempts, as they are women, they are not responded to by public authorities. These are part of the social logics and practices that also impact on perceptions of empowerment and disempowerment. As one woman interviewee noted:

'I went to the Head of Bloc [set of 10 houses]... Someone sent a police officer here, [but] it did not work. Then someone came and asked to look for [another person]... Someone who could take out this whole mess and make a pit so that all dirt would go in... [l] was not responded [to]. There was another ward secretary in the middle of this year. He said they would solve it, but I had to go to complain again for this... God sees, he understands that this person is suffering because I have nowhere else to go. The state is rejecting me. If I had a husband, that would not happen. (Interview, Household 2, Tete, Sansão Muthemba, December 2017) 
Or as another woman recalled:

Q: ... Lost document?

R: Not at all. Since my husband died, I have not received [pension] any more.

Q: Your husband, where did he work?

$\mathrm{R}$ : He did not work. We received a pension, but, when he died, I also stopped receiving the amount. I wonder if [I] do not receive it because my husband died. Nobody answered me until today... I am alive but I do not receive the pension... So I shut up because these are government matters and we have nowhere to complain. (Interview, Household 2. Nampula, Namicopo, August 2017)

There are other moral aspects that were identified in relation to gender which relate to 'lack of respect' in terms of 'hierarchy':

$\mathrm{R}$ : When we have concerns, we present them to the ward secretary and when they [the chiefs] meet, [our chief ] takes our concerns and presents to the [higher] chiefs... This is how it is done. To jump and to go straight to the [big] chiefs is not good. It is disrespectful.

$\mathrm{Q}$ : So the people have to take their concerns and present them to their ward secretary. The latter takes the concerns and shares with his 'bosses'?

$\mathrm{R}$ : Yes, if we all go, it means that there is no respect. Even here in my house, they [my children] cannot all go to my wife at the same time and ask her to buy clothes... My wife has to share that information with me...

(Interview, Household 2, Nampula, Murrupula, January 2018)

In order to consider themselves empowered, people say they need to 'just be heard' and 'have the right to speak'. 'Just be heard' has a double dimension: one passive and another active. The passive, which is dominant, refers to the simple act of speaking, but the active goes further: to participate, demand and get answers, to be considered in the decision-making process. The following short excerpt contains elements of this double meaning:

Q: ... is your opinion heard in the committee?

$\mathrm{R}$ : Yes, they listen to us. They pay attention to all we say and respect our ideas.

Q: Do you remember any opinion that was beneficial there in the committee?

$\mathrm{R}$ : The importance is in the word... because, as I said earlier, everything is recorded, just talking is important (Interview, Household 8, Tete, Mualadzi, January 2018) 
It is in Mualadzi that we find more participatory experiences and, with them, feelings of empowerment, all galvanised from the activities of the Natural Resources Management and Development Committee. Women participate, speak, complain, confront the authorities, organise protests, and obtain concessions. In January 2018, for instance, we had the opportunity to attend a meeting where this happened openly. In fact, our visit to Mualadzi's households coincided with that of a delegation from the National Assembly. Having been allowed to attend the meeting, we were able to witness the openness with which the members of the committee confronted the delegation, presenting their problems, including issues of hunger, transportation, poor care in hospitals and absence of teachers.

\subsection{Accountability}

In this research, we use accountability in its broad sense, as a two-dimensional concept (Schedler 1999). In this sense, accountability involves both answerability - the responsibility of duty-bearers to provide information and justification for their actions, and enforceability - the possibility of penalties or consequences for failing to answer accountability claims (Goetz and Jenkins 2005). However, as McGee and Gaventa (2010: 4-5) put it, '... much of what we call accountability reflects only the weaker category: answerability. While citizen-led or public initiatives often involve 'soft' peer or reputational pressure, they rarely involve strong enforceability'. This is what we found in our study locations.

In our research, we realised that most accountability processes are vertical, both ex ante and ex post, but the spaces for such processes tend to be provided. Provided spaces, also known as closed, are those controlled by the elites (Gaventa 2005). Vertical accountability, according to O'Donnell (1998) (in McGee and Gaventa 2010: 5), refers to that '... between citizens and the state', and, 'horizontal [refers] to internal checks and balances between various branches or organs of the state'. Ex ante and ex post accountability have as a reference point the moment of decision-making, the first referring to when monitoring how already made decisions are implemented, and the second to when there are hypotheses of greater engagement and, therefore, checking how decisions are made (O'Donnell in McGee and Gaventa 2010: 5).

It is local elites (e.g. village chiefs and ward secretaries) that generally provide spaces for local accountability, convening public meetings at least twice; once at the beginning of the year and once at the end. At these meetings, local leaders inform community members of the achievements of the previous year, what was, and what could not be achieved, and then plan the activities for the next 12 months. Then, for planning purposes, they collect information on the community's needs and channel it to localities who then channel it to the districts. During the meetings the chiefs share information and guidance they 
have received from their superiors, but this sometimes happens instead during home visits:

The chief has the responsibility to hold meetings here in the neighbourhood so that people know what he was told at the locality. [But] the chief here in the neighbourhood does not meet us. I do not know why... The chief's work here in the community is to solve problems. If the problem is serious and he cannot handle it, he transfers to the locality, but if [there too] they fail, it is transferred to the police and from police to Murrupula district. Therefore, the chief, when he is informed at the locality, he calls people from his neighbourhood to attend. He goes from house to house and shares the information and we go to there...

(Interview, Household 12, Nampula, Murrupula, January 2018)

The dominant expression of accountability in these contexts reveals the incidence of only one of its dimensions, answerability. Expressions include 'inform', 'update', 'accompany' and, as we mentioned above, these processes tend to be limited to the willingness of leaders to organise meetings and are not necessarily led by community demands. There are, however, more meetings and therefore greater accountability amongst the leaders themselves, on a hierarchical basis, than from them to the communities. On the contrary, in the communities the idea that prevails is that if leaders do not meet the people, the people have little chance of obtaining concessions and responses in trying to reach the leaders themselves, especially those leaders who are hierarchically superior. As discussed in the previous section, some regard, '... people to go to the big chief... is being disrespectful' (Interview, Household 2, Nampula, Murrupula, January 2018) and others consider it impossible to even question 'because these are government matters' (Interview, Household 2. Nampula, Namicopo, August 2017). Thus, in these contexts, the possibility of collective action is remote, although it does occur and there are some examples of sanction, relating to the other dimension of accountability:

Q: Who choose you as chief? Can people choose?

$\mathrm{R}$ : Yes, in case we [the leaders] do not work well, they [communities] get together and ask if they still want to continue with the person. If they say no, they choose someone else.

$\mathrm{Q}$ : Did it happen before?

R: Never with me, but I know how it works... A chieftain (régulo) ${ }^{17}$ was replaced because of his misconduct. People are summoned by the drumbeatbatuque... they play drums and announce the good news. 
The rallies are adhered... sometimes; people come from other surrounding villages. Then we have a big meeting.

(Interview with local leader, AJ, Tete, Cateme Sede, December 2018)

There are two other peculiar examples of sanction in the study locations: one in Namicopo and the other in Muliu, both in Nampula. The first is locally known as the 'anacolera phenomenon' and the second chupa sangue ('bloodsucking'). Anacolera, in Emakua, the dominant language of Nampula, comes from the word 'cholera' and literally means 'to have cholera'. When a cholera epidemic erupted in Namicopo, people attributed the responsibility to the ward secretary, claiming that he received financial benefits to allow the epidemic to spread, ravaging the neighbourhood. The people claimed that the benefits were delivered to the ward secretary by the visitors he received at his house. Some interviewees told us that it was for this reason that in 2013, people went to the ward secretary's house, destroyed it and beat the leader to death. According to them, for the following four years there were no cases of cholera in the neighbourhood. But when the disease returned in 2017, people were again in a panic. Again, information began to circulate that the new ward secretary was involved, so in one of our conversations with him, he asked our team to leave because, according to him, the community attributed responsibility to him because, being a leader, he is the first person to have contact with any visitors to the neighbourhood. According to the community, it is the visitors who are the cholera transmitters. In receiving visitors, explained the secretary, he is allowing cholera to come in which, according to the community, can only happen if he is receiving foreigners. In fact, during our December 2017 visit, while we were having a conversation with the ward secretary, people on motorcycles started shouting 'anacolera!' As the frequency with which the motorcycles passed by increased, for security reasons, our team had to leave the house.

'Bloodsucking' is a belief (André n.d.) that there is a spirit which, at night, sucks the blood of people while they sleep. The reason is unknown. There have been a few episodes in Zambézia province and in Nampula province, in addition to the districts of Angoche and Mossuril. there was a single case in Murrupula in Muliu village, causing panic among the population. A village chief said:

This really happened... in that house next door, there was a problem: at that time the husband was not there; he was an ambulance driver... so someone called him crying... That woman was crying... We forced to break open the door, as it was not opening... We found that she was spilling blood, [she was] ill. We took her to the hospital. There they gave her some pills and she stayed there for seven days. She was then recommended to drink milk and take other things. We did not know what was happening, but as it was the time people were talking about the phenomena of blood sucking, we can only 
associate it with that... but we found nothing. No one saw anything. (Interview, AP, Nampula, Murrupula, Muliu, January 2018)

However, later,

... some young people started making noise with cans saying 'the chief sold us.' They stopped there [at mine], [but] I did not respond... I did not respond because [if I had done so] it would be a problem... This lasted three nights. They said I knew [because] visitors are the ones who suck blood. [They said] Those people who come to visit me give me something and I authorise them to do the work [of sucking blood], that I am an accomplice of those who do this work of sucking blood (sic).

(Interview, AP, Nampula, Murrupula, Muliu, January 2018)

As in the case of anacolera, with the 'bloodsucking phenomenon', community members target directly local leaders. Both the ward secretary and village chief were identified as being responsible for the problems their communities faced. These people are precisely the same identified earlier as being, for some, (1) legitimate, (2) authorities, and (3) state. If we look at the question of the state, for example, that many view as a father, one can hypothesise that this father, who, for those communities, is represented by the ward secretaries and village chiefs, is responsible for all aspects of the life of its children, including, in this case, matters for which the communities cannot find an answer, hence these local representatives of state are scapegoats.

Therefore, there are expressions and practices of both empowerment and accountability in the four locations studied. In these locations, interviewees consider that there is empowerment when, among other aspects, there is inclusion, consideration and response to their demands. In turn, accountability is perceived as, above all, prestar contas (to be accounted for). However, with regard to accountability, although there are a few forms of sanction, the answerability aspect predominates, corroborating McGee and Gaventa (2010), for whom, enforcement actions in terms of accountability are scarce. In our context, people consider themselves unable to resort to enforcement due to the moral issue that it is unethical to question the superiores (superior), and because chiefs have to convene the reuniões (meetings), the main space for accountability that we identified.

There are also language issues similar to those already addressed in the literature on empowerment and accountability. As in the literature (Schedler 1999; Luttrell and Quiroz 2009), in our study locations translation of the terms 'empowerment' and 'accountability' are difficult either from the local languages used in the research (Macua and Nyungue), or from Portuguese to English, and vice versa. For 'accountability', for example, the translations of prestação de 
contas and responsabilização are indistinct when, in practice, they are relatively different. Responsabilização includes aspects of 'attribution of responsibility by/to', and prestação de contas includes information-sharing and justification. 


\section{Concluding thoughts: local authorities as intermediaries?}

In the four locations studied in this research, empowerment is understood as being mostly inclusion and participation in decision-making processes, while accountability is thought mainly as prestação de contas (to be accountable to). Expressions of empowerment include 'to know', 'be heard' and 'respected', while accountability is 'to inform', 'to accompany' and 'to blame'. In conceptual terms, there are no significant distinctions between the perceptions of empowerment and accountability identified here and those in the literature. However, in our 'fragile contexts', the possibility for collective action is relatively small. Not because there are no grievances, on the contrary, the provision of basic services is deficient and innumerable injustices prevail, but the opportunity structure, marked by political and social control, constrains people's political and social action. From our interviewees' point of view, there is an almost generalised feeling that, despite injustices and poor service delivery, they are unable (individually or collectively) to confront these when trying to engage with different authorities, including the state itself. With this feeling of inability and therefore demand-side weakness, accountability spaces tend to be top-down, not claimed by the community, and confined to the will of the chiefs to decide, when and if, for example, to hold meetings or pay household visits.

There is, however, an exception in Mualadzi. In this community, people mobilise and speak, participate, complain, confront authorities, organise protests, and obtain concessions, all galvanised by the activities of a community-based organisation, the Natural Resources Management and Development Committee. This committee, which emerged from the perception of the ineffectiveness of the local leadership, not only gained the trust of a significant portion of the Mualadzi people, but also is seen as a valid and therefore legitimate interlocutor to deal with its members' daily problems, including access to health and security services, central to this research. It is thus a kind of alternative authority for the Mualadzi population, since for them public authority is the entity able to solve their problems. In this last sense, the state, which here is not distinguished from government and the Frelimo Party, is a father who forgets and abandons his own children.

Mualadzi is a case for further research. It is important to better understand the reasons for its apparent exceptionalism within this study, especially in relation to empowerment and accountability, and deepened understanding of the intermediation role of local authorities. The authorities, described by households as being those who solve problems, in fact, do not solve the problems. They act as intermediaries between community members and higher level authorities, who are perceived as the most capable. The questions are: why? How is this intermediation done? 


\section{References}

Alexander, J. (1997) 'The Local State in Post-War Mozambique: Political Practice and Ideas about Authority', Africa: Journal of the International African Institute 67.1: 126

Alsop, R. (2004) Power, Rights and Poverty: Concepts and Connections, Washington DC: World Bank

André, B. (n.d.) Polícia Prende 21 Pessoas por Fomentar Boato sobre ‘Chupa-sangue’ na Zambézia (accessed 10 February 2019)

Arnstein, S.R. (1969) 'A Ladder of Citizen Participation', Journal of the American Institute of Planners 35.4: 216-24

Bakarat, S.R.; Freitas, L.P.; Boaventura, J.M. and MacLennan, M.L. (2016) 'Legitimidade: Uma Análise da Evolução do Conceito na Teoria Dos Stakeholders', Revista de Ciências de Administração 18.14: 66-80

Batliwala, S. (1994) 'The Meaning of Women's Empowerment: New Concepts from Action', in G. Sen, A. Germain and L.C. Chen (eds), Population Policies Reconsidered: Health, Empowerment, and Rights, Boston MA: Harvard Center for Population and Development Studies

Bertelsen, B. (2016) Violent Becomings. State Formation, Sociality, and Power in Mozambique, New York NY: Berghahn

Bierschenk, T. and de Sardan, J.P.O. (eds) (2014) States at Work: Dynamics of African Bureaucracies, Netherlands: Brill

Brautigam, D.; Fjeldstad, O-H. and Moore, M. (eds) (2008) Taxation and State Building in Developing Countries: Capacity and Consent, Cambridge: Cambridge University Press

Carbone, G. (2006) 'Comprendre Les Partis et Les Systèmes de Partis Africains', Politique Africaine 104: 18-37

Chaimite, E. (2013) 'Oposition dans un Contexte de Parti Hegemonique: Le Cas de la Renamo au Mozambique', Masters dissertation, Sciences Po Bordeaux

Collins, D.; Morduch, J.; Rutherford, S. and Ruthven, O. (2009) Portfolios of the Poor: How the World's Poor Live on \$2 a Day, Princeton NJ: Princeton University Press

Constituição da República de Moçambique (1990) Constitution of the Republic of Mozambique (accessed 12 September 2018)

Constituição da República Popular de Moçambique (1975) Constitution of the Republic of Mozambique (accessed 20 September 2017)

Cornwall, A. and Brock, K. (2005) 'What do Buzzwords do for Development Policy? A Critical Look at "Participation", "Empowerment" and "Poverty Reduction" ', Third World Quarterly 26.7: 1043-60

Cornwall, A. and Edwards, J. (2010) 'Introduction: Negotiating Empowerment', IDS Bulletin 41.2: 1-9, DOI:10.1111/j.1759-5436.2010.00117.x (accessed 13 January 2021)

De Brito, L. (2010) 'Le Difficile Chemin de la Démocratisation', Politique Africaine 117: 5-22 (accessed 25 January 2018)

De Brito, L. (1991) 'Le Frelimo et la Construction de l'État National au Mozambique. Le sens de la Référence au Marxisme (1962 - 1963)', PhD thesis, Université de Paris VIII

Del Rosso Jr., S. (1995) 'The Insecure State: Reflections on "The State" and "Security" in a Changing World', Daedalus 124.2: 175-83

DFID (2011) A Preliminary Mapping of the Evidence Base for Empowerment and Accountability, London: Department for International Development

Diaz, F. (2014) How Democratic is Mozambique? Preview of Upcoming Elections (accessed 13 January 2019)

Dom, R. (2018) Taxation and Accountability in Sub-Saharan Africa New Evidence for a Governance Dividend, Overseas Development Institute Working Paper 544, London: ODI

Englebert, P. (2002) State Legitimacy and Development in Africa, Boulder CO: Lynne Rienner 
Gastil, J. (2000) By Popular Demand: Revitalizing Representative Democracy through Deliberative Elections, Berkeley CA: University of California Press

Gaventa, J. (2005) Reflections of the Uses of the 'Power Cube' Approach for Analyzing the Spaces, Places and Dynamics of Civil Society Participation and Engagement, CFP Evaluation Series 4, The Hague, Netherlands: MBN Secretariat

Gentili, A.M. (2005) 'Party, Party Systems and Democratisation in Sub-Saharan Africa', paper presented at the Sixth Global Forum on Reinventing Government, Seoul, 24-27 May

Goetz, A.M. and Jenkins, R. (2005) 'Introduction', in A.M. Goetz and R. Jenkins (eds), Re-inventing Accountability: Making Democracy Work for Human Development, Basingstoke: Palgrave Macmillan

Green, D. (2017) Theories of Change for Promoting Empowerment and Accountability in Fragile and Conflict-Affected Settings, IDS Working Paper 449, Brighton: Institute of Development Studies (accessed 13 January 2021)

Habermas, J. (1997) Direito e Democracia: Entre Facticidade e Validade, Rio de Janeiro: Tempo Brasileiiro Hama, H. (2017) 'State Security, Societal Security, and Human Security', Journal of International Relations 21.1: $1-19$

Hanlon, J. (1991) Mozambique: Who Calls the Shots?, Bloomington IN: Indiana University Press

Hutchison, M.L and Johnson, K. (2011) 'Capacity to Trust? Institutional Capacity, Conflict, and Political Trust in Africa, 2000-2005', Journal of Peace Research 48: 737-52, DOI: 10.1177/0022343311417981 (accessed 13 January 2021)

Ivison, D. (2017) ‘Pluralising Political Legitimacy', Postcolonial Studies 35.4: 118-30, DOI: 10.1080/13688790.2017.1334289 (accessed 12 January 2019)

Kato, J. and Tanaka, S. (2019) 'Does Taxation Lose its Role in Contemporary Democratisation? State Revenue Production Revisited in the Third Wave of Democratisation', European Journal of Political Research 58: 184-208

Lake, D.A. and Farris, C. (2014) 'International Trusteeship: External Authority in Areas of Limited Statehood', Governance 27.4: 569-87

Lei 9/91, de 18 de Julho, Regula o Exercicio à Liberdade de Reuniao e Manifestaçao, Boletim da Republica, Série 19, Maputo

Loureiro, M.; Joshi, A.; Barnes, K. and Chaimite, E. (2020) Governance Diaries: An Approach to Governance Research from the Ground Up, IDS Working Paper 534, Brighton, Institute of Development Studies (accessed 13 January 2021)

Luhmann, N. (1980) Legitimação Pelo Procedimento, Brasília: Universidade de Brasília

Luttrell, C. and Quiroz, S. (2009) Understanding and Operationalising Empowerment, Overseas Development Institute Working Paper 308, London: ODI

McGee, R. and Gaventa, J. (2010) Review of Impact and Effectiveness of Transparency and Accountability Initiatives: Synthesis Report, Brighton: Institute of Development Studies (accessed 13 January 2021)

Mcloughlin, C. with Idris, I. (2016) Fragile States: Topic Guide, Birmingham: GSDRC, University of Birmingham (accessed 13 January 2021)

Meneses, M.P.G. (n.d.) Traditional Authorities in Mozambique: Between Legitimisation and Legitimacy (accessed 13 January 2019)

Nuvunga, A. (2014) 'From the Two-party to the Dominant Party System in Mozambique, 1994-2012. Framing Frelimo Party Dominance in Context', PhD thesis, Erasmus University of Rotterdam

Orre, A. (2010) 'Entrenching the Party-State in the Multiparty Era: Opposition Parties, Traditional Authorities and New Councils of Local Representatives in Angola and Mozambique', PhD thesis (accessed 25 February 2018)

Piron, L-H. and Watkins, F. (2004) DFID Human Rights Review: A Review of How DFID has Integrated Human Rights into its Work, Report for DFID, London

Rawls, J. (1993) Political Liberalism, New York NY: Columbia University Press

Risse, T. and Stollenwerk, E. (2018) 'Legitimacy in Areas of Limited Statehood', Annual Review of Political Science 21: 403-18 
Sartori, G. (1976) Parties and Party Systems: A Framework for Analysis, Cambridge: Cambridge University Press

Schedler, A. (1999) 'Conceptualising Accountability', in A. Schedler, L. Diamond and M.F. Plattner (eds), The Self-Restraining State: Power and Accountability in New Democracies, London: Lynne Rienner SDC (2004) Creating the Prospect of Living a Life in Dignity Principles Guiding the SDC in its Commitment to Fighting Poverty, Berne: Swiss Agency for Development and Cooperation

Sen, G. (1997) Empowerment as an Approach to Poverty, Working Paper Series 97.07, background paper for the UNDP Human Development Report, New York: United Nations Development Programme

Sumich, J. and Honwana, J. (2007) Strong Party, Weak State Frelimo and State Survival through the Mozambican Civil War: An Analytical Narrative on State-Making, Crisis States Working Papers Series 2, London: London School of Economics

Taela, K.; Shankland, A. and Awortwi, N. (2016) Mozambique: Country and Intervention Scoping Report', Action for Empowerment and Accountability Programme, Brighton: A4EA, Institute of Development Studies (accessed 13 January 2019)

Unsworth, S. (2010) An Upside Down View of Governance, Centre for the Future State, Brighton: Institute of Development Studies (accessed 13 January 2021) 


\section{(2) institute of development \\ studies}

Delivering world-class research, learning and teaching that transforms the knowledge, action and leadership needed for more equitable and sustainable development globally.

Institute of Development Studies

Library Road

Brighton, BN1 9RE

United Kingdom

+44 (0)1273606261

ids.ac.uk

Charity Registration Number 306371

Charitable Company Number 877338

(C) Institute of Development Studies 2021 